Original Article

\title{
DISEASE PREVENTION FUNCTIONAL FOODS FROM THE HIGH POTENTIAL MMP-2 INHIBITION ACTIVITY OF PINEAPPLE JUICE GRANULE
}

\author{
WARINTORN RUKSIRIWANICH ${ }^{{ }^{*}}$, TANAKARN CHAITEPb, RATCHAPON LERTWICHA ${ }^{\mathrm{b}}$, PENSAK JANTRAWUTa
}

aPharmaceutical and Natural Products Research and Development Unit, Department of Pharmaceutical Sciences, Faculty of Pharmacy, Chiang Mai University, Chiang Mai 50200, Thailand, bDepartment of Pharmaceutical Sciences, Faculty of Pharmacy, Chiang Mai University, Chiang Mai 50200, Thailand

Email: warintorn.ruksiri@hotmail.com

Received: 25 Dec 2018 Revised and Accepted: 15 Feb 2019

ABSTRACT

Objective: This study aimed to compare total phenolic acid and protein contents as well as free radical scavenging, enzyme activities of fresh and fermented pineapple juice.

Methods: The dried pineapple juice, prepared by freeze-drying and granulation method, with high bioactive compounds (total phenolic acid and protein contents) and biological activities (scavenging and enzyme activities) from fresh and fermented pineapple juice was developed and evaluated. The selected granules were evaluated for their stability at the 3 different temperatures for 3 mo. The pineapple juice granules were tested for the non-cytotoxic concentration by the SRB assay and Matrix metalloproteinase 2 (MMP-2) inhibition activity on human skin fibroblast.

Results: The pineapple juice granules, the single-coated granules of pineapple juice showed a higher percentage of yield but lower biological contents and activities than that triple-coated granules. The triple-coated granules of pineapple juice exhibited the highest total protein content $(1.53 \pm 0.10 \mathrm{mg}$ Bovine serum albumin equivalent (BSAE)) with scavenging activity (51.15 $\pm 5.94 \%)$, and enzyme activity (4156.18 \pm 74.78 Casein digestion unit (CDU)/mg). For gelatinolytic activity on MMP-2, the freeze-dried powder and triple-coated granules of pineapple juice indicated the highest MMP-2 inhibition activity of $50.74 \%$ and $48.48 \%$, respectively.

Conclusion: The triple-coated granules of pineapple juice could be served as a disease prevention functional food due to its easy operation, high total phenolic acid, and protein contents with high potential MMP-2 inhibition activity.

Keywords: Disease prevention, Functional food, Granules, MMP-2 inhibition, Pineapple juice

(C) 2019 The Authors. Published by Innovare Academic Sciences Pvt Ltd. This is an open access article under the CC BY license (http://creativecommons.org/licenses/by/4.0/) DOI: http://dx.doi.org/10.22159/ijpps.2019v11i4.31630

\section{INTRODUCTION}

Thailand is one of the world's major producers of pineapple besides Malaysia, Philippines, Indonesia, and South Africa [1]. Pineapple [Ananas comosus (L.) Merr.] is consumed fresh or in various processed forms [2]. Pineapple juice is a popular product due to its very pleasant aroma, flavor, and numerous functional properties [3]. Pineapple juice contains a variety of minerals, especially manganese, as well as amino acids, various sugars, vitamins, and polyphenols [4]. The pineapple juice contains phenolic acids such as p-coumaric acid, caffeic acid, ferulic acid, sinapic acid, $p$-coumaroylquinic acid, feruloyl glucose, $p$ hydroxybenzoic acid, $p$-hydroxybenzaldehyde, and syringic acid $[5,6]$. Not only polyphenols which contribute to its antioxidant activity but pineapple juice also contains amino acids. Major free amino acids identified in the pineapple juice include asparagine, proline, aspartic acid, serine, glutamic acid, tyrosine, valine, and isoleucine [7]. The composition of free amino acids is significantly higher in pineapple juice in comparison with grape juice and apple juice [8]. It is considered as a functional drink due to its nutritional compounds which have many health-promoting properties. However, pineapple juice which has high water content and highly perishable can increase the growth of microorganism that leads to low lifespan.

Therefore, pineapple juice should be processed into a dried form in order to overcome these losses and also to extend the shelf life of pineapple juice for its availability during the off-season [9]. According to Kadam, et al. 2008, dried form products such as powder bring about a substantial reduction in weight and volume, minimizing packaging and storage, thus reducing transportation costs [10]. There are various drying techniques applicable to produce dried products such as tray drying, vacuum drying, spray drying, and freeze drying [11-13].

Lactic acid fermentation is one of the oldest ways of food processing and preservation, liable to keep or increase the safety, nutritional, sensory and shelf-life properties of foods. Lactic acid bacteria (LAB) are a group of gram-positive bacteria, producing lactic acid as the main product of carbohydrate fermentation. During fermentation, LAB produces substances such as bacteriocins, exo-polysaccharides (EPS), aroma compounds, enzymes, B vitamins (mainly folate, riboflavin, cobalamin) or low-calorie polyols (mannitol, sorbitol), which enhance the safety, nutritional quality, sensory properties or antioxidant activities of food [14]. The improved preservation of ascorbic acid, glutathione, phenolic compounds, and antioxidant activity was observed following lactic acid fermentation of smoothies and tomato juice with Lactobacillus plantarum, Pediococcus pentosaceus or Weissella cibaria $[15,16]$. In this study, we aimed to compare total phenolic acid and protein contents as well as free radical scavenging and enzyme activities of fresh and fermented pineapple juice. Then, the selected pineapple juice was developed as dried forms and tested for their biological contents and activities.

\section{MATERIALS AND METHODS}

\section{Sample preparation}

The pineapples (Ananas comosus) were collected from the local market in Chiang Mai, Thailand during March-April. The pineapple juice was mechanically collected from fresh pineapples $(1 \mathrm{~kg})$ and filtrated through the Whatman ${ }^{\mathrm{TM}}$ filter paper no. 1. The clear pineapple extract was pasteurized at $72{ }^{\circ} \mathrm{C}$ for $15 \mathrm{~s}$ and immediately placed in an ice bath for $10 \mathrm{~min}$ [17].

\section{Lactobacillus plantarum preparation}

L. plantarum SS-2, obtained from Asst. Prof. Dr. Chaiyawat Chaiyasut, was cultured in optimizing De Man, Rogosa and Sharpe (MRS) medium in $5 \% \mathrm{CO}_{2}$ at $37{ }^{\circ} \mathrm{C}$. After incubation, cells were harvested by centrifugation at $10,000 \mathrm{rpm}$ for $10 \mathrm{~min}$ and washed

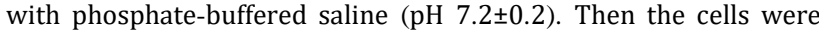


diluted with Phosphate Buffered Saline (PBS) buffer at the concentration of $1.0 \times 10^{6}$ cells $/ \mathrm{ml}$ for further studies.

\section{Fermentation}

About $10 \mathrm{ml}$ of pineapple juice with $1.0 \times 10^{6}$ cells $/ \mathrm{ml}$ of $L$. plantarum was allowed for fermentation process in a sterile container. The pineapple juice without $L$. plantarum inoculum was served as a control, and the fermenter was incubated at $37{ }^{\circ} \mathrm{C}$. Samples were collected with regular intervals as following at $0,2,4$, $6,8,10,12,18,24,30,36,48,60,72,96,120,144,168,192,216$, $240,264,288,312$, and $336 \mathrm{~h}$. Then the samples were subjected to the determination of total phenolic and protein contents and tested for antioxidant and enzyme activities.

\section{Evaluation of samples}

The total phenolic and protein contents, antioxidant and enzyme activities of samples were determined.

\section{Total phenolic contents}

The Folin-Ciocalteu method [18] was used to determine the total phenolic content. Briefly, the sample was mixed with an equal volume of $1 \mathrm{~N}$ Folin-Ciocalteu reagent and $1 \mathrm{ml}$ of $20 \%$ sodium carbonate, incubated for $2 \mathrm{~h}$ at room temperature and measured the absorbance of the supernatant at $730 \mathrm{~nm}$. The total phenolic contents were calculated from the calibration curve of the standard gallic acid. The total phenolic content was expressed in mg of gallic acid equivalents (GAE)/g of the extract.

\section{Total protein contents}

Protein quantification was determined by using Bradford protein assay, in which $0.2 \mathrm{mg} / \mathrm{ml}$ Bovine serum albumin (BSA) stock solution was used and the standard graph was plotted [19]. The standard graph protein content of the samples was calculated.

\section{Antioxidant activity through DPPH radical scavenging activity assay}

The DPPH radical scavenging activity of the sample was determined by a modified method previously described [20]. The percentages of DPPH radical scavenging activity were calculated using equation (1)

$$
\text { Scavenging }(\%)=\frac{\text { (Abs control-Abs sample) }}{\text { Abs control }} \times 100 \ldots \text { (1) }
$$

The $\mathrm{IC}_{50}$ value which was the concentration of the sample that scavenged $50 \%$ of the DPPH radical was determined.

\section{Enzyme activity assay}

Enzyme activity assay was performed according to the universal protease assay [21] in which casein was used as a substrate ( $0.65 \%$ casein along with $0.03 \mathrm{M}$ cysteine and $1 \mathrm{mmol}$ EDTA) and l-tyrosine $(0.2 \mathrm{mg} / \mathrm{ml})$ was used as a standard. Absorbance was taken at $660 \mathrm{~nm}$ using a spectrophotometer. From the standard curve, the activity of the protease in the samples was determined in terms of Casein Digestion Units (CDU) from tyrosine standard curve.

The total phenolic and protein contents, antioxidant and enzyme activities of samples were presented as the score index which calculated using equation (2).

$$
\begin{gathered}
\text { Score index }=\frac{\text { total protein content at } n h}{\text { total protein content at initial }}+ \\
\frac{\text { total phenolic content at } n h}{\text { total phenolic content at initial }}+\frac{\text { scavenging activity at } n h}{\text { scavenging activity at initial }}+ \\
\frac{\text { enzyme activity at } n h}{\text { enzyme activity at initial }} \text {....... (2) }
\end{gathered}
$$

\section{Drying process}

\section{Freeze-drying processing}

The selected fresh pineapple juice was collected at the optimum time (selected based on the score index) and snap frozen at $40{ }^{\circ} \mathrm{C}$ followed by drying using freeze-dryer (Labconco Corporation, Kansas, MO, USA) to obtain the fermented pineapple juice powder.

\section{Granulation of fermented pineapple juice}

The corn starch and Avicel ${ }^{\circledR}$ PH-101 were mixed at 1:1 ratio to prepare carrier base. Then, the selected fresh pineapple juice was slowly added to the carrier base, until the paste saturation point was obtained. The carrier base with juice was sieved through a screen with $850 \mu \mathrm{m}$ openings ( $20 \mathrm{mesh}$ ) to get the homogeneous-sized granules and dried at $30^{\circ} \mathrm{C}$ for $24 \mathrm{~h}$. This process was repeated three times to obtain the triple-coated granules of fermented juice.

\section{Stability test}

The triple-layered pineapple juice granule were evaluated for the physical, phytochemical contents, and biological stability under -20 , 4 and $25{ }^{\circ} \mathrm{C}$. The samples were tested for the total phenolic and protein contents as well as antioxidant and enzyme activities at the initial and after 1, 2 and 3 mo.

\section{Cell toxicity on human skin fibroblasts}

\section{Cell culture}

The primary normal human skin fibroblasts were derived from the skin plastic surgery and cultured under the standard conditions in the complete culture medium containing $\alpha$-modified Eagles culture medium (MEM-Alpha) supplemented with $10 \% \mathrm{v} / \mathrm{v}$ fetal bovine serum (FBS), penicillin $(100 \mathrm{U} / \mathrm{ml})$ and streptomycin $(100 \mathrm{mg} / \mathrm{ml})$. Cells were incubated at a temperature-controlled and humidified incubator (CCL-050B-8, Esco ${ }^{\circledR}$, Singapore) with $5 \% \mathrm{CO}_{2}$ at $37^{\circ} \mathrm{C}$.

\section{Determination of non-cytotoxic concentration by the SRB assay}

The samples were tested for cell proliferation of the normal human skin fibroblasts by the Sulforhodamine B (SRB) assay as previously described [22]. L-ascorbic acid (0.00001-1 mg/ml) was used as a positive control. The cells were plated at a density of $1.0 \times 10^{5}$ cells per well in 96-well plates and left overnight for cell attachment on the plate in $5 \% \mathrm{CO}_{2}$ atmosphere at $37^{\circ} \mathrm{C}$. Cells were then exposed to five serial concentrations of the extracts $(0.00001-1 \mathrm{mg} / \mathrm{ml})$ for 24 h. After incubation, the adherent cells were fixed in situ, washed and dyed with SRB. The bound dye was solubilized and the absorbance was measured at $540 \mathrm{~nm}$ by a 96-well reader (EZ Read 400 Flexi, Biochrom ${ }^{\circledR}$, England). The experiments were done in triplicate. The percentages of cell proliferation were calculated according to equation (3).

$$
\text { Cell growth }(\%)=\frac{\text { Abs sample-Abs blank }}{\text { Abs control-Abs blank }} \times 100 \ldots \text { (3) }
$$

Gelatinolytic activity (Zymography) of MMP-2 inhibition on human skin fibroblast

The samples (freeze-dried powder, single-and triple-coated granules of pineapple juice and fresh pineapple juice) were investigated for the gelatinolytic activity of MMP-2 inhibition in comparing to the standard L-ascorbic acid. A monolayer of $5 \times 10^{5}$ cells of normal human skin fibroblasts was maintained in the culture medium without FBS for $24 \mathrm{~h}$, treated with the samples, the standard Lascorbic acid at $0.1 \mathrm{mg} / \mathrm{ml}$ and incubated for $48 \mathrm{~h}$. The culture supernatants were collected. To assess the gelatinolytic activities of MMP-2 in the culture media, Sodium Dodecyl Sulfate Polyacrylamide Gel Electrophoresis (SDS-PAGE) zymography using gelatin as a substrate was performed. Briefly, $20 \mu \mathrm{l}$ of the cell culture supernatant was suspended in the loading buffer, $0.125 \mathrm{M}$ Tris ( $\mathrm{pH}$ 6.8), $4 \%$ SDS and $0.04 \%$ bromophenol blue, without prior denaturation and run on $10 \%$ SDS polyacrylamide gel containing 1 $\mathrm{mg} / \mathrm{ml}$ gelatin. After electrophoresis, gels were washed to remove SDS and incubated for $20 \mathrm{~min}$ in the renaturing buffer $(50 \mathrm{mmol}$ Tris, $5 \mathrm{mmol} \mathrm{CaCl}_{2}, 0.02 \% \mathrm{NaN}_{3}, 2.5 \%$ Triton X-100). The gels were then incubated for $24 \mathrm{~h}$ at $37{ }^{\circ} \mathrm{C}$ in developing buffer of $50 \mathrm{mmol}$ Tris (pH 7.5), $5 \mathrm{mmol} \mathrm{CaCl}_{2}, 0.02 \% \mathrm{NaN}_{3}$ and $1 \%$ Triton X-100 to allow gelatin degradation by Matrix metalloproteinases (MMPs). Gels were subsequently stained with $0.5 \%$ Coomassie brilliant blue G-250 and de-stained in 30\% methanol and 10\% acetic acid (v/v) to detect gelatinolytic activity [23]. Gelatinase activity was detected as a white band on a blue background. The gel was documented by a gel documentation system (Gel Doc ${ }^{\mathrm{TM}}$ EZ Gel, Bio-Rad Laboratories, USA) and analyzed by Image lab ${ }^{\mathrm{TM}}$ software 5.1 (Bio-Rad Laboratories Inc., USA). The volume (intensity) multiplied by the 
number of pixels of the bands on the gel was determined as the relative MMP-2 content (intensity unit) [24]. The percentages of MMP-2 inhibition in comparing to the control (the untreated systems) were calculated by equation (4).

$$
\text { MMP }-2 \text { inhibition }(\%)=100-\left(\frac{\mathrm{MMP}-2 \text { content sample }}{\mathrm{MMP}-2 \text { content control }} \times 100\right) \ldots . .(4)
$$

The assays were done in three independent separate experiments. The potency of MMP-2 inhibition of the samples was compared with the positive control (L-ascorbic acid).

\section{Statistical analysis}

The results are expressed as mean \pm standard deviation (SD). Kruskal-Wallis test was used to evaluate the significance of differences at $p$-value $<0.05$.

\section{RESULTS AND DISCUSSION}

\section{Biological contents and activities of fresh and fermented pineapple juice}

The total phenolic and protein contents, free radical scavenging and enzyme activities of fresh and fermented pineapple juice were shown in table 1 . The results showed that L. plantarum meditated fermentation of pineapple juice was not influenced differently on the quality of the fresh juice. The highest amount of total phenolic and protein contents, free radical scavenging activity of $5 \mathrm{mg} / \mathrm{ml}$, and protease enzyme activity was found in the fresh pineapple juice at the initial of the fermentation of about $0.115 \pm 0.008 \mathrm{mg} \mathrm{GAE}$, $2.03 \pm 0.04 \mathrm{mg}$ Bovine serum albumin equivalent (mg BSAE), $37.52 \pm 1.88 \%, 2674.09 \pm 109.02 \mathrm{CDU} / \mathrm{mg}$, respectively. After $2 \mathrm{~h}$ of the fermentation, the free radical scavenging activity $(37.63 \pm 1.51 \%)$ slightly increased but was not significantly different at 95\% confident intervals. The high values of phenolic contents and antioxidant activity of fresh pineapple juice maybe due to phenolic compounds in pineapple juice. Besides the phenolic compounds, pineapple juice contains both l-ascorbic acid and dehydroascorbic acid. l-ascorbic acid is an effective antioxidant [25]. The l-ascorbic acid content of fresh pineapple juice is reported to range from 9.2 to $93.8 \mathrm{mg} / 100 \mathrm{ml}[26,27]$. Pineapple juice exhibited intermediate antioxidant activity in comparison with other fruit juices (pineapple juice $>$ orange juice $>$ cherry juice) [28]. Moreover, the highest total phenolic content in the extract may be responsible for antioxidant activity [29].

Major free amino acids identified in the pineapple juice include asparagine, proline, aspartic acid, serine, glutamic acid, tyrosine, valine, and isoleucine [7]. The juice contains ample amounts of asparagine, serine, threonine, and glycine [4]. The composition of free amino acids is significantly higher in pineapple juice in comparison with grape juice and apple juice [8]. Fresh pineapple juice also contains bromelain enzyme which may attribute to high enzyme activity in this study. The initial score index which calculated from the sum of total phenolic and protein contents, free radical scavenging and protease enzyme activities at each different hour divided by its value at initial. The initial score index was generated to compare the fermentation time with respect to the selected parameters. The initial index values were shown in fig. 1. From the initial index values, the fermentation was not shown the positive impact on any total phenolic and protein contents either scavenging and enzyme activities of the pineapple juice. Thus, the fresh pineapple juice was selected, and further dried to preserve its phytochemical nature of the fruit. Moreover, the fresh and fermented pineapple juice were also physically observed. The fermented pineapple juice was found of the increase in alcoholic smell and acidic level. The $\mathrm{pH}$ of the pineapple juice reduced from 5.0 to 3.5 when it was fermented.

Table 1: Total phenolic and protein contents, free radical scavenging and enzyme activities of fresh and fermented pineapple juice

\begin{tabular}{|c|c|c|c|c|c|c|c|c|c|}
\hline \multicolumn{2}{|c|}{ Times } & \multicolumn{2}{|c|}{$\begin{array}{l}\text { Total phenolic content (mg } \\
\text { GAE) }\end{array}$} & \multicolumn{2}{|c|}{$\begin{array}{l}\text { Total protein content } \\
\text { (mg BSAE) }\end{array}$} & \multicolumn{2}{|c|}{ Scavenging activity $\left(\mathrm{IC}_{50}\right)$} & \multicolumn{2}{|c|}{ Enzyme activity (CDU/mg) } \\
\hline Day & Hour & Fresh & Fermented & Fresh & Fermented & Fresh & Fermented & Fresh & Fermented \\
\hline \multirow[t]{9}{*}{1} & 0 & $0.115 \pm 0.008^{\mathrm{a}}$ & $0.102 \pm 0.009^{b}$ & $2.03 \pm 0.04^{\mathrm{a}}$ & $1.96 \pm 0.10^{\mathrm{a}}$ & $37.52 \pm 1.88$ & $33.42 \pm 2.67$ & $2674.09 \pm 109.02^{\mathrm{a}}$ & $2360.59 \pm 42.57^{a}$ \\
\hline & 2 & $0.098 \pm 0.008^{\mathrm{c}}$ & $0.084 \pm 0.006$ & $1.98 \pm 0.14^{b}$ & $1.84 \pm 0.07$ & $37.63 \pm 1.51$ & $32.18 \pm 0.64$ & $2300.27 \pm 59.87^{b}$ & $1857.89 \pm 37.24$ \\
\hline & 4 & $0.095 \pm 0.002$ & $0.092 \pm 0.001^{\mathrm{c}}$ & $1.85 \pm 0.09$ & $1.86 \pm 0.09$ & $32.14 \pm 1.61$ & $31.12 \pm 2.18$ & $2093.26 \pm 41.94$ & $1714.16 \pm 24.88$ \\
\hline & 6 & $0.099 \pm 0.007^{b}$ & $0.090 \pm 0.005$ & $1.93 \pm 0.12$ & $1.87 \pm 0.13^{\mathrm{c}}$ & $35.16 \pm 2.46$ & $30.54 \pm 1.53$ & $1818.99 \pm 112.78$ & $1877.01 \pm 60.55$ \\
\hline & 8 & $0.115 \pm 0.006^{\mathrm{a}}$ & $0.105 \pm 0.006^{\mathrm{a}}$ & $1.79 \pm 0.16$ & $1.82 \pm 0.15$ & $33.41 \pm 2.67$ & $30.36 \pm 1.82$ & $2070.84 \pm 145.80$ & $1760.31 \pm 51.92$ \\
\hline & 10 & $0.099 \pm 0.006^{b}$ & $0.090 \pm 0.006$ & $1.82 \pm 0.13$ & $1.88 \pm 0.04^{b}$ & $31.24 \pm 0.62$ & $29.87 \pm 2.69$ & $2024.69 \pm 51.74$ & $1789.98 \pm 62.27$ \\
\hline & 12 & $0.095 \pm 0.010$ & $0.085 \pm 0.002$ & $1.96 \pm 0.02^{c}$ & $1.75 \pm 0.12$ & $33.21 \pm 2.32$ & $29.61 \pm 2.07$ & $1762.29 \pm 22.08$ & $1942.28 \pm 62.99$ \\
\hline & 18 & $0.093 \pm 0.007$ & $0.091 \pm 0.008$ & $1.79 \pm 0.09$ & $1.71 \pm 0.09$ & $31.32 \pm 1.57$ & $30.64 \pm 0.31$ & $1844.70 \pm 29.77$ & $1988.43 \pm 47.48$ \\
\hline & 24 & $0.097 \pm 0.012$ & $0.085 \pm 0.002$ & $1.81 \pm 0.11$ & $1.64 \pm 0.10$ & $33.02 \pm 1.98$ & $31.27 \pm 1.56$ & $1653.51 \pm 67.53$ & $2135.45 \pm 76.00^{c}$ \\
\hline \multirow[t]{3}{*}{2} & 30 & $0.099 \pm 0.005^{b}$ & $0.082 \pm 0.006$ & $1.75 \pm 0.12$ & $1.52 \pm 0.14$ & $34.09 \pm 3.07$ & $28.14 \pm 1.69$ & $1971.95 \pm 28.75$ & $1978.54 \pm 29.95$ \\
\hline & 36 & $0.091 \pm 0.005$ & $0.073 \pm 0.001$ & $1.74 \pm 0.03$ & $1.71 \pm 0.12$ & $35.87 \pm 2.51$ & $28.96 \pm 2.03$ & $1658.12 \pm 40.97$ & $1853.93 \pm 41.39$ \\
\hline & 48 & $0.089 \pm 0.006$ & $0.068 \pm 0.003$ & $1.69 \pm 0.15$ & $1.64 \pm 0.02$ & $33.19 \pm 0.33$ & $29.37 \pm 0.59$ & $1911.95 \pm 46.34$ & $1694.38 \pm 48.93$ \\
\hline \multirow[t]{2}{*}{3} & 60 & $0.086 \pm 0.013$ & $0.080 \pm 0.006$ & $1.78 \pm 0.04$ & $1.69 \pm 0.08$ & $32.14 \pm 1.61$ & $29.83 \pm 2.68$ & $1629.77 \pm 28.85$ & $1737.90 \pm 34.14$ \\
\hline & 72 & $0.085 \pm 0.008$ & $0.078 \pm 0.004$ & $1.91 \pm 0.13$ & $1.71 \pm 0.10$ & $31.61 \pm 1.90$ & $29.11 \pm 0.58$ & $1303.42 \pm 87.41$ & $1686.47 \pm 36.93$ \\
\hline 4 & 96 & $0.097 \pm 0.002$ & $0.073 \pm 0.008$ & $1.68 \pm 0.03$ & $1.81 \pm 0.13$ & $36.01 \pm 2.52$ & $27.14 \pm 1.90^{\mathrm{a}}$ & $1451.10 \pm 19.71$ & $1647.57 \pm 62.89$ \\
\hline 5 & 120 & $0.089 \pm 0.006$ & $0.082 \pm 0.002$ & $1.52 \pm 0.08$ & $1.64 \pm 0.03$ & $33.14 \pm 0.66$ & $29.63 \pm 0.59$ & $962.57 \pm 37.52$ & $1761.63 \pm 30.90$ \\
\hline 6 & 144 & $0.084 \pm 0.011$ & $0.071 \pm 0.004$ & $1.69 \pm 0.12$ & $1.62 \pm 0.15$ & $31.24 \pm 2.81$ & $28.13 \pm 1.41$ & $1758.33 \pm 67.27$ & $1820.97 \pm 51.44$ \\
\hline 7 & 168 & $0.092 \pm 0.005$ & $0.079 \pm 0.003$ & $1.64 \pm 0.08$ & $1.73 \pm 0.03$ & $34.21 \pm 0.68$ & $29.52 \pm 2.07$ & $2127.54 \pm 60.46$ & $1737.90 \pm 37.45$ \\
\hline 8 & 192 & $0.081 \pm 0.006$ & $0.078 \pm 0.004$ & $1.79 \pm 0.20$ & $1.76 \pm 0.12$ & $30.11 \pm 2.11^{\mathrm{b}}$ & $28.91 \pm 1.45$ & $892.02 \pm 61.79$ & $1742.51 \pm 43.40$ \\
\hline 9 & 216 & $0.080 \pm 0.004$ & $0.073 \pm 0.005$ & $1.84 \pm 0.04$ & $1.77 \pm 0.04$ & $29.89 \pm 0.60^{\mathrm{a}}$ & $29.35 \pm 3.23$ & $1022.56 \pm 69.01$ & $1458.36 \pm 33.67$ \\
\hline 10 & 240 & $0.085 \pm 0.009$ & $0.079 \pm 0.006$ & $1.81 \pm 0.09$ & $1.79 \pm 0.09$ & $31.86 \pm 1.59$ & $27.65 \pm 0.55^{c}$ & $945.43 \pm 18.89$ & $1083.22 \pm 50.09$ \\
\hline 11 & 264 & $0.089 \pm 0.013$ & $0.071 \pm 0.001$ & $1.73 \pm 0.07$ & $1.83 \pm 0.13$ & $33.21 \pm 2.32$ & $26.49 \pm 1.32$ & $2155.23 \pm 10.15^{c}$ & $2161.16 \pm 58.90^{b}$ \\
\hline 12 & 288 & $0.084 \pm 0.004$ & $0.077 \pm 0.005$ & $1.64 \pm 0.08$ & $1.72 \pm 0.09$ & $31.14 \pm 1.56$ & $27.68 \pm 1.11$ & $1439.24 \pm 11.93$ & $1653.51 \pm 56.83$ \\
\hline 13 & 312 & $0.081 \pm 0.003$ & $0.075 \pm 0.004$ & $1.54 \pm 0.11$ & $1.61 \pm 0.18$ & $30.17 \pm 3.32^{\mathrm{c}}$ & $28.11 \pm 1.41$ & $1407.59 \pm 22.64$ & $1237.49 \pm 33.54$ \\
\hline 14 & 336 & $0.084 \pm 0.004$ & $0.073 \pm 0.004$ & $1.69 \pm 0.14$ & $1.58 \pm 0.03$ & $31.46 \pm 0.63$ & $27.33 \pm 1.91^{b}$ & $1281.08 \pm 10.80$ & $861.19 \pm 35.29$ \\
\hline
\end{tabular}

\section{Dried forms of pineapple juice}

The fresh pineapple juice was selected and dried through freezedrying and granulation methods, the yield of powder from freezedrying was $15.53 \pm 1.24 \%$ and appeared as yellow sticky, and hygroscopic texture (fig. 2). Thus, to improve the powdery texture, granulation method was employed. The corn starch and Avicel ${ }^{\circledR}$ were used to generate granule in $1: 1$ ratio. The yield of a single- coated granule $(25.10 \pm 2.76 \%)$ was higher than triple-coated granules $(12.88 \pm 1.49 \%)$. Then, the total phenolic and protein contents, free radical scavenging and protease enzyme activities of freeze-dried powder and granules of fresh pineapple juice were compared. The results show that triple-coated granule of pineapple juice exhibited higher enzyme activity $(4156.18 \pm 74.78 \mathrm{CDU} / \mathrm{mg}$ of extract), scavenging activity (51.15 $\pm 5.94 \%)$ than the pineapple juice powder from the freeze-drying method which has an enzyme 
activity of $3950.48 \pm 461.14 \mathrm{CDU} / \mathrm{mg}$ of extract and scavenging activity of $49.27 \pm 3.75 \%$ (table 2). However, fresh pineapple juice showed the highest total phenolic and protein contents. Thus, the triple-coated granules of pineapple juice were selected for further stability study. Considering the perishable nature of pineapple, it is necessary to preserve them through drying method. At present, there is a growing interest in the use of conventional drying techniques. Common methods of drying processes include solar drying, air drying, spray drying, and freeze drying [30]. Solar and air drying perhaps are the oldest method of drying with a disadvantage of dependence on weather condition and prone to insect infestation, dust, and dirt contamination [31]. Whereas, spray and freeze-drying are not cost effective and not energy efficient, though they produce good quality fruit powders [30]. Therefore, the need arises to develop a suitable low-cost technology for making fruit powders. This study showed the potential of producing pineapple juice granules by granulation method with high biological contents and activities.
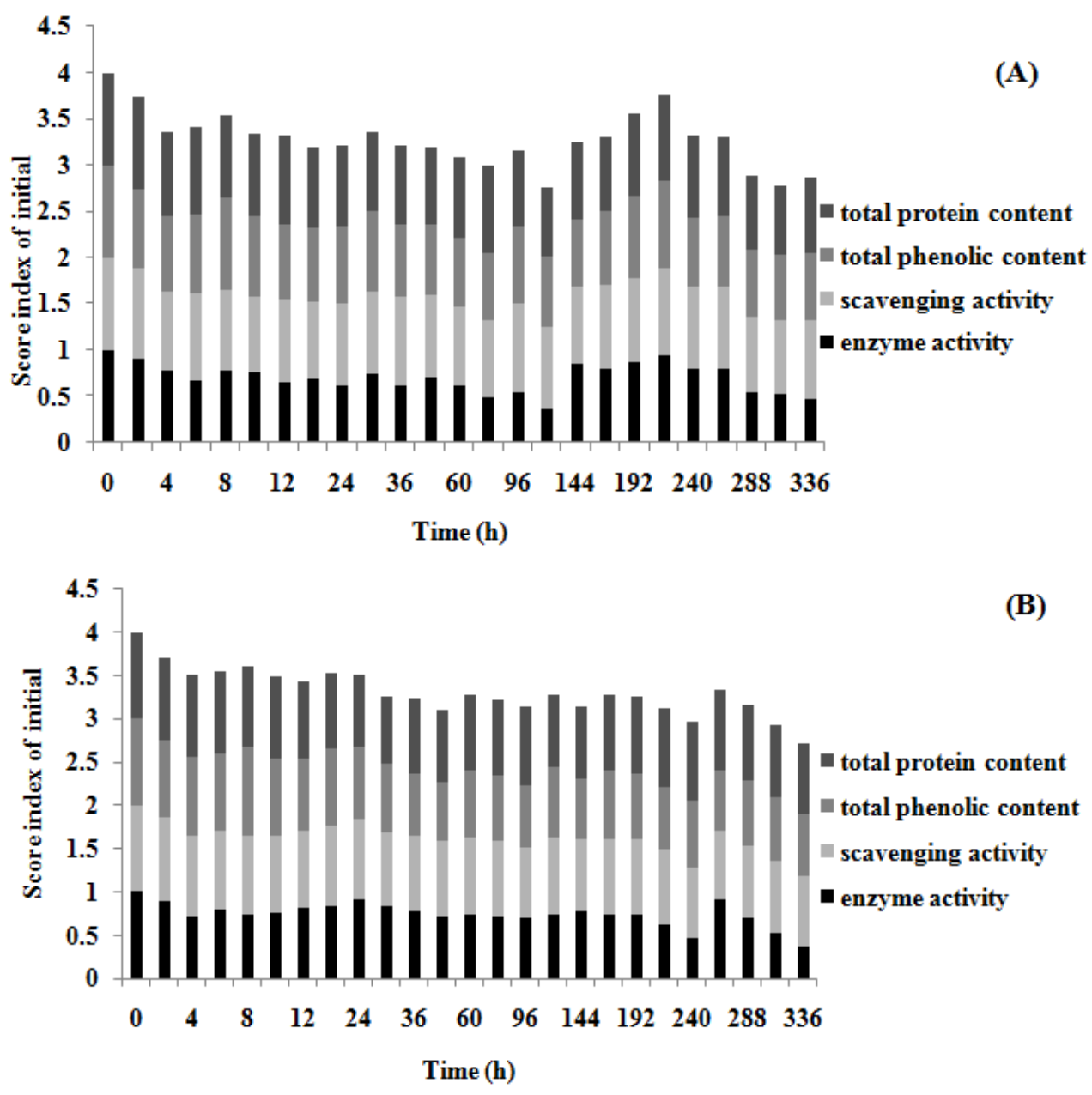

Fig. 1: The score index of total phenolic and protein contents, free radical scavenging and enzyme activities of (A) fresh and (B) fermented pineapple juice
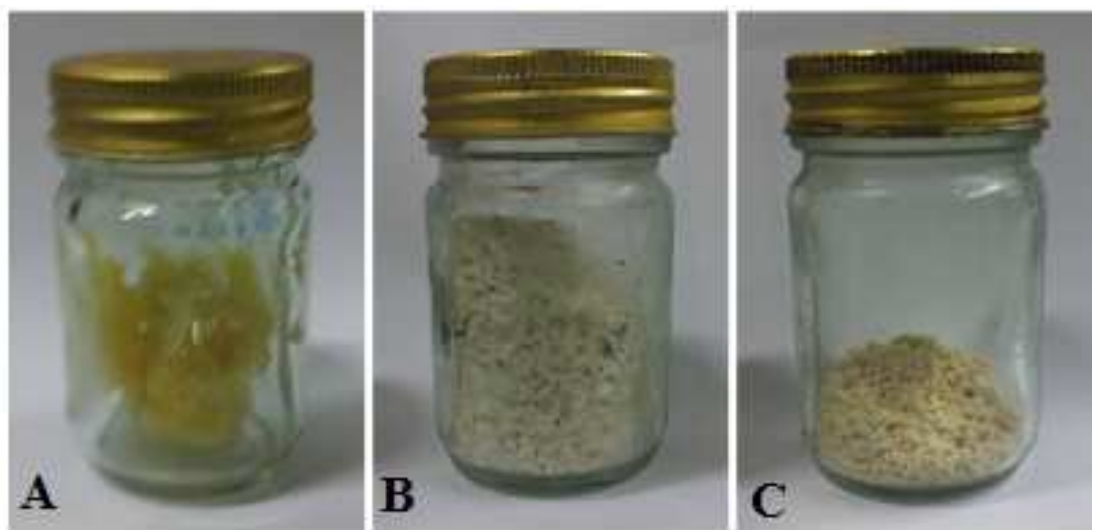

Fig. 2: The fresh pineapple juice powder from (A) freeze-dried process, (B) single- and (C) triple-layered pineapple juice granules 
Table 2: Total phenolic and protein contents, free radical scavenging and enzyme activities of fresh pineapple juice and dried forms of pineapple juice

\begin{tabular}{|c|c|c|c|c|}
\hline Sample & $\begin{array}{l}\text { Total phenolic } \\
\text { content (mg GAE) }\end{array}$ & $\begin{array}{l}\text { Total protein } \\
\text { content (mg BSAE) }\end{array}$ & $\begin{array}{l}\text { Enzyme activity (CDU/mg of } \\
\text { extract) }\end{array}$ & $\begin{array}{l}\text { Scavenging } \\
\text { activity }(\%)\end{array}$ \\
\hline Fresh pineapple juice & $0.091 \pm 0.005$ & $2.03 \pm 0.04$ & $1271.12 \pm 404.13$ & $33.98 \pm 1.01$ \\
\hline $\begin{array}{l}\text { Single-layered pineapple juice } \\
\text { granules }\end{array}$ & $0.014 \pm 0.002$ & $0.34 \pm 0.06$ & $1384.21 \pm 121.17$ & $28.62 \pm 9.75$ \\
\hline $\begin{array}{l}\text { Triple-layered pineapple juice } \\
\text { granules }\end{array}$ & $0.052 \pm 0.001$ & $1.53 \pm 0.10$ & $4156.18 \pm 74.78$ & $51.15 \pm 5.94$ \\
\hline Freeze-dried pineapple juice & $0.079 \pm 0.005$ & $1.50 \pm 0.25$ & $3950.48 \pm 461.14$ & $49.27 \pm 3.75$ \\
\hline l-ascorbic acid & - & - & - & $92.21 \pm 3.39$ \\
\hline
\end{tabular}

\section{Stability of pineapple juice granule}

The triple-layered fresh pineapple juice granules were kept in the laminated package at $-20,4$, and $25{ }^{\circ} \mathrm{C}$ for three months. It was found that the 3-month storage condition did not affect the physical nature of the pineapple juice granule. The total phenolic and protein contents were found up to $80 \%$ in 3 different temperatures compared to the initial (fig. 3), while free radical scavenging and protease enzyme activity were slightly decreased, but not significantly $(p<0.05)$. These results suggested that the triple-layered fermented pineapple juice granules should be stored at low temperature $\left(4{ }^{\circ} \mathrm{C}\right)$ to preserve the natural phytochemical content and biological activities. Thus, pineapple juice granules could be a more practical form for the daily use than their liquid counterpart which can prolong the shelf life of the juice products.

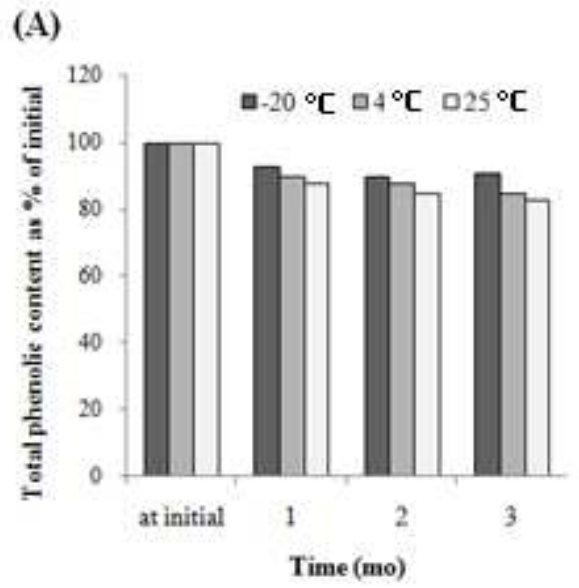

(C)

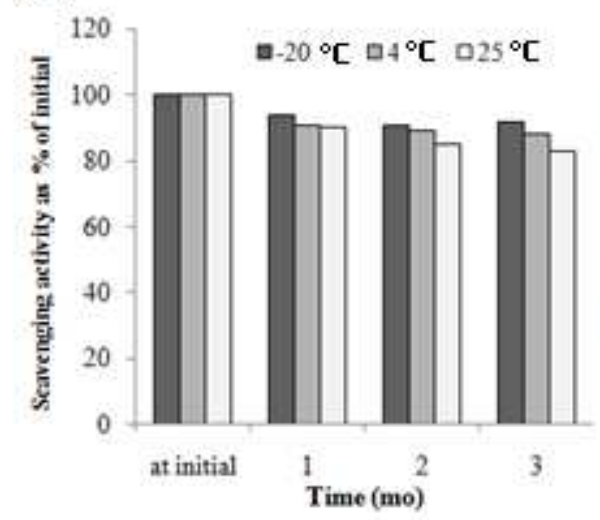

(B)

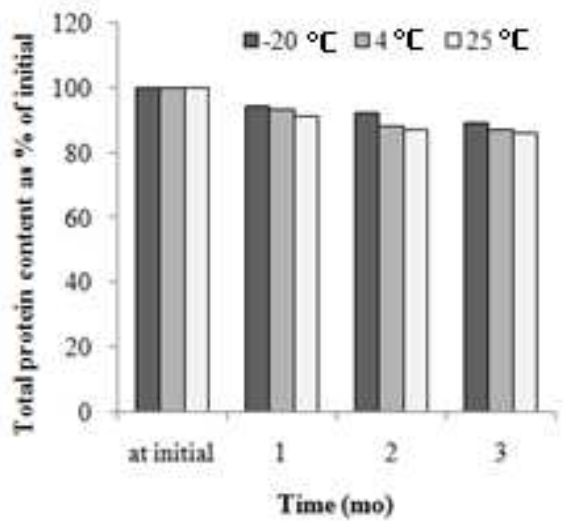

(D)

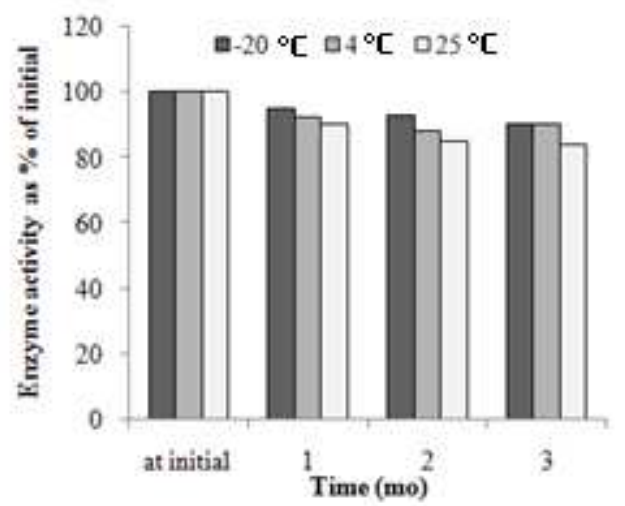

Fig. 3: The stability of triple-layered pineapple juice granules at $-20^{\circ} \mathrm{C}, 4^{\circ} \mathrm{C}$, and $25{ }^{\circ} \mathrm{C}$ which determined by $(\mathrm{A})$ total phenolic and (B) protein contents, $(C)$ free radical scavenging and (D) enzyme activities

Gelatinolytic activity on MMP-2 inhibition of pineapple juice samples

The cell proliferation by the SRB study has indicated not only fresh pineapple juice exhibited no toxicity on human skin fibroblasts but also the freeze-dried powder, single-and triple-coated granules of pineapple juice gave no cytotoxicity. The cell viability was higher than $90 \%$ in all samples. The inhibitory effects of the gelatinolytic activity on MMP-2 expression of the pineapple juice samples and the standard ascorbic acid were shown in fig. 4. Since all samples were not cytotoxic to human skin fibroblasts by the SRB assay, the MMP-2 inhibition was not due to the cytotoxicity. The fresh pineapple juice gave the lowest relative MMP-2 expression of $17.08 \pm 2.12 \%$. The freeze-dried powder and triple-coated granule of pineapple juice indicated the highest MMP-2 inhibition activity of $50.74 \pm 4.54 \%$ and $48.48 \pm 3.49 \%$, respectively, which were higher than ascorbic acid (31.19 $\pm 2.93 \%)$ of 1.63 and 1.55 times, respectively. 


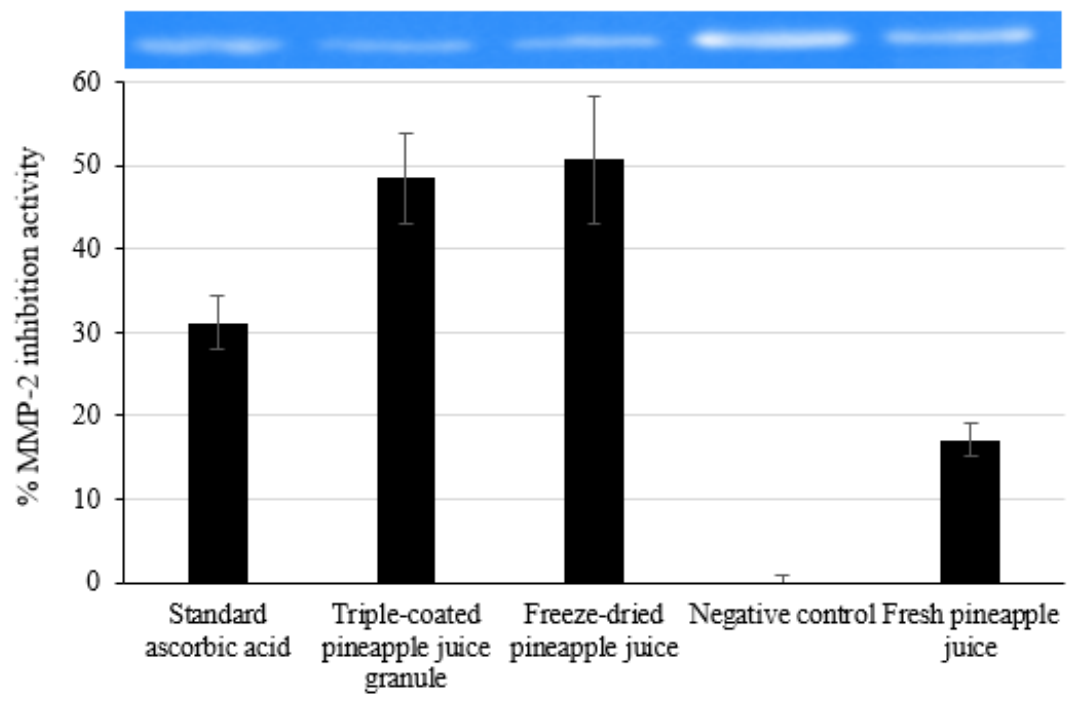

Fig. 4: MMP-2 inhibition activity of the single-, triple-coated pineapple juice granules, freeze-dried pineapple juice powder, and fresh pineapple juice compared to standard ascorbic acid. (A) Zymograms and (B) the percentages of MMP-2 inhibition

As known, MMPs are a family of zinc-containing endoproteinases that degrade extracellular matrix (ECM) components. MMPs have important roles in the development, physiology, and pathology of many organs (heart, blood vessels, kidney, and skin). Metalloproteases also play key roles in adverse cardiovascular remodeling, atherosclerotic plaque formation and plaque instability, vascular smooth muscle cell (SMC) migration and restenosis that lead to coronary artery disease (CAD), and progressive heart failure [32]. Moreover, MMP-2 plays a critical role in the destruction of articular cartilage in rheumatoid arthritis (RA), osteoarthritis (OA), psoriatic arthritis (PsA), and the spondyloarthropathies [33]. Recently, the strong interaction between platelets and tumor cells influenced by Matrix metalloproteinases/Tissue inhibitors of metalloproteinases (MMPs/TIMPs) was found. The triple-coated granule of pineapple showed the high potential MMP-2 inhibition activity which not only has the benefits of the skin aging, cell inflammation [34], myocardial infarction [35], heart failure [36], but also atherosclerosis and tumor cell development.

Moreover, bromelain which is a complex natural mixture of proteolytic enzymes derived from pineapple has been shown to inhibit the invasiveness of human cancer cells by suppressing matrix metalloproteinase 9 (MMP-9) expression [37, 38]. However, MMP-2 and MMP-9 are mainly secreted by tumor cells and stromal cells in the form of zymogens. After activation via hydrolysis, MMP-2 and MMP-9 degrade basement membrane (BM) type IV collagen, affecting the ability of BMs to impede tumor cell movement [39]. Hence, the triple-coated granule of pineapple juice could be beneficial as functional foods for cardiovascular disease, arthritis, skin aging and tumor cell progression via MMP- 2 inhibition activity

\section{CONCLUSION}

Fresh pineapple juice exhibited higher content of total phenolic and protein than the fermented one. It should be developed into a dry form in order to increase its shelf-life and prevent the growth of the microorganism. The Freeze-drying and granulation methods were used to prepare a dry form of pineapple juice in this study. Even though, the high percentage yield of pineapple juice powder was recovered by freeze-drying method, granulation method produced the high quality and preferred physical traits in the dried pineapple juice product. Therefore, the granulation process was appropriated to prepare pineapple juice granules. The triple-coated pineapple juice granules were superior in biological activities than the singlecoated one. The stability study of the selected pineapple juice granules supported their high total phenolic and protein contents as well as scavenging and enzyme activities for 3 mo at $4{ }^{\circ} \mathrm{C}$. The freeze-dried powder and triple-coated granules of pineapple juice indicated higher MMP-2 inhibition activity than ascorbic acid of about 1.63 and 1.55 times, respectively. This study will be beneficial for further development of triple-coated granule of pineapple juice as a disease prevention functional food since its easy operation, high total phenolic acid, and protein contents and high potential MMP-2 inhibition activity which not only show advantages of the cell inflammation, aging, myocardial infarction, heart failure, but also atherosclerosis and tumor cells development.

\section{ACKNOWLEDGEMENT}

This work was supported by the Chiang Mai University Junior Researcher Fellowship Program.

\section{AUTHORS CONTRIBUTIONS}

Conceptualization, Ruksiriwanich, W.; Methodology, Ruksiriwanich, W.; Formal Analysis, Chaitep, T.; Investigation, Lertwicha, R.; Resources, Lertwicha, R.; Writing-Original Draft Preparation, Jantrawut, P; Writing-Review and Editing, Ruksiriwanich, W.; Supervision, Ruksiriwanich, W.; Project Administration, Ruksiriwanich, W.; Funding Acquisition, Ruksiriwanich, W.

\section{CONFLICTS OF INTERESTS}

The authors report no conflicts of interest. The authors alone are responsible for the content and writing of this article.

\section{REFERENCES}

1. Farimin A, Nordin E. Physical properties of powdered rosellepineapple juice-effects of maltodextrin. Nat Conf Postgrad Res 2009. p. 90-7.

2. Avallone S, Guiraud JP, Brillouet JM, Teisson C. Enzymatic browning and biochemical alterations in black spots of pineapple [Ananas comosus (L.) Merr.]. Curr Microbiol 2003;47:113-8.

3. Rattanathanalerk M, Chiewchan N, Srichumpoung W. Effect of thermal processing on the quality loss of pineapple juice. J Food Eng 2005;66:259-65.

4. Elkins ER, Lyon R, Huang C, Matthys A. Characterization of commercially produced pineapple juice concentrate. J Food Compos Anal 1997; 10:285-98.

5. Wen L, Wrolstad R. Phenolic composition of authentic pineapple juice. J Food Sci 2002;67:155-61.

6. Menon A, Priya VV, Gayathri R. Preliminary phytochemical analysis and cytotoxicity potential of pineapple extract on oral cancer cell lines. Asian J Pharm Clin Res 2016;9:140-3. 
7. Gawler JH. Constituents of canned Malayan pineapple juice I.amino-acids, non-volatile acids, sugars, volatile carbonyl compounds and volatile acids. J Sci Food Agric 1962;13:57-61.

8. Dizy M, Martín Alvarez PJ, Cabezudo MD, Carmen Polo M. Grape, apple and pineapple juice characterisation and detection of mixtures. J Sci Food Agric 1992;60:47-53.

9. Saxena R, Arora V. Consumers of processed fruit and vegetable products: an analysis of buying behaviour. Indian Food Ind 1997; 16:25-36

10. Kadam DM, Samuel DV, Chandra P, Sikarwar HS. Impact of processing treatments and packaging material on some properties of stored dehydrated cauliflower. Int J Food Sci Technol 2008;43:1-14.

11. Tuyen CK, Nguyen MH, Roach PD. Effects of pre-treatments and air drying temperatures on colour and antioxidant properties of Gac fruit powder. Int J Food Eng 2011;7:44-50.

12. Tuyen CK, Nguyen MH, Roach PD. Effects of spray drying conditions on the physicochemical and antioxidant properties of the gac (Momordica cochinchinensis) fruit aril powder. J Food Eng 2010;98:385-92.

13. Tran TH, Nguyen MH, Zabaras D, Vu LT. Process development of gac powder by using different enzymes and drying techniques. J Food Eng 2008;85:359-65.

14. Beena Divya J, Kulangara Varsha K, Madhavan Nampoothiri K, Ismail B, Pandey A. Probiotic fermented foods for health benefits. Eng Life Sci 2012;12:377-90.

15. Di Cagno R, Minervini G, Rizzello CG, De Angelis M, Gobbetti M. Effect of lactic acid fermentation on antioxidant, texture, color and sensory properties of red and green smoothies. Food Microbiol 2011;28:1062-71.

16. Di Cagno R, Surico RF, Paradiso A, De Angelis M, Salmon JC, Buchin S, et al. Effect of autochthonous lactic acid bacteria starters on health-promoting and sensory properties of tomato juices. Int J Food Microbiol 2009;128:473-83.

17. Blümel J, Schmidt I, Willkommen H, Lower J. Inactivation of parvovirus B19 during pasteurization of human serum albumin. Transfusion 2002;42:1011-8.

18. Yeh CT, Yen GC. Effect of vegetables on human phenolsulfotransferases in relation to their antioxidant activity and total phenolics. Free Radical Res 2005;39:893-904.

19. Bradford MM. A rapid and sensitive method for the quantitation of microgram quantities of protein utilizing the principle of protein-dye binding. Anal Biochem 1976; 72:248-54.

20. Tachibana Y, Kikuzaki H, Lajis NH, Nakatani N. Antioxidative activity of carbazoles from Murraya koenigii leaves. J Agric Food Chem 2001;49:5589-94.

21. Indrajeet A, Ojha S, Singh S, Chakravarty I, Kundu S. Extraction and purification of bromelain from pineapple fruit pulp and peel and comparative study of enzymatic activities. Int J Basic Appl Biol 2017;4:4-7.

22. Papazisis KT, Geromichalos GD, Dimitriadis KA, Kortsaris AH. Optimization of the sulforhodamine B colorimetric assay. J Immunol Methods 1997;208:151-8.
23. Kim S, Kim Y, Kim JE, Cho KH, Chung JH. Berberine inhibits TPA-induced MMP-9 and IL-6 expression in normal human keratinocytes. Phytomedicine 2008;15:340-7.

24. Manosroi A, Jantrawut P, Akihisa T, Manosroi W, Manosroi J. In vitro anti-aging activities of Terminalia chebula gall extract. Pharm Biol 2010;48:469-81.

25. Luximon Ramma A, Bahorun T, Crozier A. Antioxidant actions and phenolic and vitamin $C$ contents of common mauritian exotic fruits. J Sci Food Agric 2003;83:496-502.

26. Cárnara M, Diez C, Torija E. Chemical characterization of pineapple juices and nectars. Principal components analysis. Food Chem 1995;54:93-100.

27. Kabasakalis V, Siopidou D, Moshatou E. Ascorbic acid content of commercial fruit juices and its rate of loss upon storage. Food Chem 2000;70:325-8.

28. Ramadan Hassanien MF. Total antioxidant potential of juices, beverages and hot drinks consumed in Egypt screened by DPPH in vitro assay. Grasas Aceites 2008;59:254-9.

29. Ruksiriwanich W, Sirithunyalug J, Boonpisuttinant K, Jantrawut P. Potent in vitro collagen biosynthesis stimulating and antioxidant activities of edible mushroom Volvariella volvacea aqueous extract. Int J Pharm Pharm Sci 2014;6:406-12.

30. Maisnam D, Rasane P, Dey A, Kaur S, Sarma C. Recent advances in conventional drying of foods. J Food Technol Pres 2017;1:25-34

31. Sontakke M, Salve S. Solar drying technologies: a review. Int J Eng Sci 2015;4:29-35.

32. Mittal B, Mishra A, Srivastava A, Kumar S, Garg N. Chapter onematrix metalloproteinases in coronary artery disease, in advances in clinical chemistry, G. S. Makowski, Editor. Elsevier; 2014. p. 1-72.

33. Malemud CJ, Chapter seven-matrix metalloproteinases and synovial joint pathology, in progress in molecular biology and translational science. RA Khalil. Editor. Academic Press; 2017. p. 305-25.

34. Sayanna D, Sudip M. Current developments on antiinflammatory natural medicines. Asian J Pharm Clin Res 2018;11:61-5.

35. Ma Y, Iyer RP, de Castro Bras LE, Toba H, Yabluchanskiy A, Deleon-Pennell Kristine Y, et al. Chapter 4-cross talk between inflammation and extracellular matrix following myocardial infarction, in Inflam Heart Fail. WM Blankesteijn, R Altara. Editors. Academic Press: Boston; 2015. p. 67-79.

36. DeLeon Pennell KY, Meschiari CA, Jung M, Lindsey ML. Chapter two-matrix metalloproteinases in myocardial infarction and heart failure, in Prog Mol Biol Transla Sci. RA Khalil. Editor. Academic Press; 2017. p. 75-100.

37. Li Q , Withoff $\mathrm{S}$, Verma IM. Inflammation-associated cancer: NF$\kappa \mathrm{B}$ is the lynchpin. Trends Immunol 2005;26:318-25.

38. Philchenkov A. Caspases: potential targets for regulating cell death. J Cell Mol Med 2004;8:432-44.

39. Zhang $\mathrm{W}$, Wang $\mathrm{F}, \mathrm{Xu} \mathrm{P}$, Miao $\mathrm{C}$, Zeng $\mathrm{X}$, Cui $\mathrm{X}$, et al. Perfluorooctanoic acid stimulates breast cancer cells invasion and up-regulates matrix metalloproteinase-2/-9 expression mediated by activating NF-кB. Toxicol Lett 2014;229:118-25. 